\title{
Morphological variation in Leptodactylus lutzi (Anura, Leptodactylidae) with description of its advertisement call and notes on its courtship behavior
}

\author{
Philippe J. R. Kok ${ }^{1}$, Marcelo N. C. Kokubum², Ross D. MacCulloch ${ }^{3}$, and Amy Lathrop ${ }^{3}$ \\ 1 Department of Vertebrates, Royal Belgian Institute of Natural Sciences, 29 rue Vautier, B-1000 Brussels, Belgium. \\ E-mail: Philippe.Kok@naturalsciences.be. \\ 2 Laboratório de Ecologia e Sistemática de Anuros Neotropicales, Instituto de Biologia, Universidade Federal de \\ Uberlândia, CEP 38400-902, Uberlândia, Minas Gerais, Brazil, and Programa de Pós-graduação em Ecologia - I.B., \\ Campus Universitário Darcy Ribeiro - UnB, 70919-970, Brasília, DF, Brazil. E-mail : mnckokubum@unb.br. \\ ${ }^{3}$ Centre for Biodiversity and Conservation Biology, Royal Ontario Museum, 100 Queen’s Park, Toronto, Ontario M5S \\ 2C6, Canada. E-mails: rossm@rom.on.ca, amyl@rom.on.ca.
}

\begin{abstract}
Morphological variation in Leptodactylus lutzi (Anura, Leptodactylidae) with description of its advertisement call and notes on its courtship behavior. Prior to this study, Leptodactylus lutzi was known only from three localities in west-central Guyana. We refer here to a series of 60 additional specimens of L. lutzi collected in Kaieteur National Park, Mount Ayanganna, Mount Wokomung and the Merume Mountains in the Pakaraima Mountains region, substantially extending the known distribution of the species. We provide a revised diagnosis and an expanded description of $L$. lutzi discussing the extent of color-pattern variation in the species. Additionally, we describe its advertisement call and provide data on its reproductive biology.
\end{abstract}

Keywords: Anura, Leptodactylidae, Leptodactylus lutzi, advertisement call, color variation, courtship behavior, Guiana Shield, Guyana.

\section{Introduction}

The composition of the genus Leptodactylus was recently changed to include the former genera Adenomera and Lithodytes (Frost et al. 2006), placed into the same subgenus Leptodactylus (Lithodytes). Almeida and Angulo

Received 23 January 2007.

Accepted 10 May 2007.

Distributed June 2007.
(2006) briefly discussed this arrangement and placed all members of the former genus Adenomera into the Leptodactylus marmoratus group (Heyer 1973), rather than nesting them with Lithodytes. We follow this more conservative arrangement.

Frogs of the Leptodactylus marmoratus group are usually difficult to identify due to poor discriminant morphological characters and, sometimes, high intraspecific variability in color and patterns (Heyer 1973, De la Riva 1996, 
Kwet and Angulo 2002). Some species are virtually impossible for an inexperienced eye to distinguish, and acoustic characters are invaluable tools to solve specific identification problems. It is assumed that undescribed species masquerade under the same name, identifiable by their vocalizations only (see Angulo and Icochea 2003, Angulo et al. 2003, Kokubum and Giaretta 2005). Molecular data would also be useful in case of challenging identifications.

Three species of the Leptodactylus marmoratus group are reported from Guyana: Leptodactylus andreae Müller, 1923, L. hylaedactylus (Cope, 1868), and L. lutzi (Heyer, 1975) (Señaris and MacCulloch 2005). Leptodactylus andreae and L. hylaedactylus have a broad distribution in northern and central west South America, and are fairly well known, even though records of these species from Guyana are scarce (see below). Little information is available on Leptodactylus lutzi, a species described in 1975 on the basis of three specimens and currently known only from three localities in western Guyana: Chenapou River, Demerara Falls and Mount Ayanganna (Heyer 1975, Señaris and MacCulloch 2005).

During the course of intensive surveys in the Pakaraima Mountains region Philippe J. R. Kok (PJRK), Ross D. MacCulloch (RDM) and Amy Lathrop (AL) secured several specimens of $L$. lutzi. Leslie Minter from the University of Limpopo, South Africa (UL) collected additional specimens in the Merume Mountains region (northeastern Pakaraimas). Remarkable intraspecific variation in pattern and color was observed among our 60-specimen sample. In March 2006 PJRK and Paul Benjamin (Chenapou, Guyana) recorded the advertisement call of three males in Kaieteur National Park (KNP), and made some observations on the species' reproductive behavior. With the aim of updating our knowledge of this poorly known, endemic frog, we provide here a revised diagnosis and an expanded species description plus the description of the advertisement call and notes on its reproductive behavior.

\section{Materials and Methods}

Data used in the present study were gathered during eight field trips between October 2000 and June 2006 in different locations in the Pakaraima Mountains region, Guyana: Kaieteur National Park, Mount Ayanganna, Mount Wokomung, and the Merume Mountains, between 430-1400 m elevation (see Appendix I for exact coordinates of specimens examined). Coordinates and elevations were determined using Global Positioning Systems (GPS). Most of the 60 specimens were collected by hand on or in the leaf litter; five specimens from Kaieteur National Park (KNP) were caught using drift fences and pitfall traps. Specimens were fixed in a $10 \%$ formalin solution and transferred to $70 \%$ ethanol for permanent storage. Liver tissue samples were removed from most specimens and preserved in 95\% ethanol for further molecular studies. Specimens are deposited at the Institut Royal des Sciences Naturelles de Belgique, Brussels, Belgium (IRSNB), the Royal Ontario Museum, Toronto, Canada (ROM), and the United States National Museum, Washington, USA (USNM). Tissues are deposited at the IRSNB and the ROM. Color in life was taken from field notes and photographs. Sex was confirmed by presence of vocal slits and dissection.

All preserved specimens (except USNM 546152, not included in this study) were measured to the nearest $0.01 \mathrm{~mm}$ with electronic digital calipers; all measurements were rounded to one decimal point following Hayek et al. (2001). Terminology and diagnostic characters mainly follow Almeida and Angulo (2006). The following measurements were taken: snout-vent length (SVL), head length from corner of mouth to tip of snout (HL); head width at corner of mouth (HW); snout length from anterior corner of eye to tip of snout (SL); eye to naris distance from anterior corner of eye to centre of naris (EN); internarial distance (IN); eye length (EL); interorbital distance (IO); horizontal diameter of tympanum (TYM); forearm length, from elbow 
to proximal edge of palmar tubercle (FAL); hand length, from proximal edge of palmar tubercle to tip of Finger III (HDL); tibia length from outer edge of flexed knee to heel (TL); foot length, from proximal edge of outer metatarsal tubercle to tip of Toe IV (FL). Number of vomerine teeth was also counted, on the right side (VTR) and on the left side (VTL).

PJRK and Paul Benjamin recorded the advertisement calls of three males in March 2006 on a Maxell DM60 digital audiotape using a Sony DAT TCD-D100 recorder with a Sony ECM-MS907 microphone. Recordings of two vouchered males were made from less than $1 \mathrm{~m}$ away from the frogs. Recording of the third, unvouchered specimen was made from $\mathrm{ca} .4 \mathrm{~m}$ from the frog; this recording was used only to obtain the call rate (calls/minute). Males emitted calls continuously, and we selected 2-3 min of each of the three calls recorded. Temperature during recordings was taken with an Oregon Scientific thermometer and varied from 23$25^{\circ} \mathrm{C}$. The following parameters were considered in the analysis: call length, call rate, call rise time, dominant frequency, fundamental frequency, and frequency modulation. We analyzed spectral parameters of the calls (2048point Fast Fourier Transform, frequency resolution at $21.5 \mathrm{~Hz}$, low and high band limits at 1500 and $7000 \mathrm{~Hz}$, respectively) and prepared audiospectrograms with Sound Ruler (Gridi Papp 2004) at a sampling rate of $22050 \mathrm{~Hz}$ with 16-bit resolution. Acoustic terminology follows Cocroft and Ryan (1995), except for fundamental frequency, which follows Duellman and Pyles (1983), and call rate, which is understood here as the number of calls (notes) per minute.

\section{Results}

Differences in call, coloration and size allow easy identification, and Leptodactylus lutzi cannot be confused with any other member of the L. marmoratus group. Only three other species of the marmoratus group are found in the Guiana Shield area (Señaris and MacCulloch
2005, Boistel et al. 2006): Leptodactylus andreae, L. heyeri (Boistel, de Massary and Angulo 2006) and L. hylaedactylus. All three of these species have distinct advertisement calls, lack the typical dark triangular seat patch and the yellow, orange or red spotting or mottling on posterior black surface of thigh, and lack forearm tubercles. Additionally L. lutzi is a larger species with a maximum SVL of $34.1 \mathrm{~mm}$ (Heyer 1975) [28.9 mm in L. andreae (Heyer 1973), $25.8 \mathrm{~mm}$ in L. heyeri (Boistel et al. 2006), and $31.0 \mathrm{~mm}$ in L. hylaedactylus (Heyer 1973)]. Leptodactylus lutzi further differs from $L$. andreae and L. hylaedactylus by its yellow belly (white in $L$. andreae and $L$. hylaedactylus) and from $L$. heyeri by the absence of two distinct pairs of parallel dorsolateral folds (present in L. heyeri).

Morphological variation ( $N=59 ; 26$ males, 19 females, 14 juveniles) - Descriptive statistics of specimens examined are in Table 1. Body robust, many specimens have abdominal fat deposits. Large body size for a species of the marmoratus group. Outline of snout variable due to the presence of a fleshy proboscis (shovel-shaped) on snout in males (Figure 1), from rounded to sub-elliptical in dorsal view and from rounded to acuminate in profile; head wider than long. Canthus rostralis round, indistinct, loreal region slightly concave to concave. Nostrils anterolateral, closer to tip of snout than to eyes. Tympanum distinct, its diameter about $60 \%$ eye length in adults. Pupil horizontal, elliptic. Supratympanic fold well developed, extending from eye to arm insertion in $96 \%$ of the Kaieteur specimens, $60 \%$ of the Ayanganna specimens, 50\% of the Wokomung specimens and $50 \%$ of the Merume specimens, not reaching arm insertion in the remaining specimens; a large ovoid glandular patch present at angle of jaw in most specimens. Interorbital space flat, slightly greater than internarial distance. Vocal sac bilobate, subgular, internal or barely expanded externally, a pair of vocal slits present in males. Tongue ovoid, elongate. 
Table 1 - Measurements (in mm) of specimens of Leptodactylus lutzi. Mean \pm SD are followed by the range in parentheses. Abbreviations: SVL, snout-vent length; HL, head length; HW, head width; SL, snout length; EN, eye to naris distance; IN, internarial distance; EL, eye length; IO, interorbital distance; TYM, horizontal diameter of tympanum; FAL, forearm length; HDL, hand length; TL, tibia length; FL, foot length; VTL, number of vomerine teeth on the right side; VTR, number of vomerine teeth on the left side.

\begin{tabular}{cccc}
\hline Measurement & Males $(\mathbf{N}=\mathbf{2 6})$ & Females $(\mathbf{N}=\mathbf{1 9})$ & Juveniles (N= 14) \\
\hline SVL & $30.2 \pm 1.7(25.7-33.5)$ & $31.2 \pm 1.7(27.1-34.0)$ & $18.6 \pm 3.7(11.7-23.7)$ \\
HL & $9.2 \pm 1.0(7.6-11.0)$ & $9.1 \pm 1.1(8.0-11.0)$ & $6.0 \pm 1.5(3.9-8.4)$ \\
HW & $11.1 \pm 0.7(9.1-12.6)$ & $11.4 \pm 0.6(10.5-12.5)$ & $7.0 \pm 1.5(4.6-9.6)$ \\
SL & $4.9 \pm 0.4(3.7-5.8)$ & $4.7 \pm 0.5(4.0-5.6)$ & $3.0 \pm 0.6(1.9-4.0)$ \\
EN & $2.7 \pm 0.2(2.1-3.2)$ & $2.8 \pm 0.2(2.4-3.1)$ & $1.7 \pm 0.3(1.0-2.4)$ \\
IN & $2.8 \pm 0.2(2.5-3.1)$ & $2.9 \pm 0.1(2.7-3.3)$ & $1.9 \pm 0.3(1.3-2.3)$ \\
EL & $3.2 \pm 0.2(2.7-3.6)$ & $3.3 \pm 0.1(3.0-3.5)$ & $2.2 \pm 0.3(1.6-2.7)$ \\
IO & $3.0 \pm 0.3(2.4-3.4)$ & $3.1 \pm 0.4(2.5-3.8)$ & $2.0 \pm 0.5(1.3-3.0)$ \\
TYM & $1.8 \pm 0.3(1.3-2.3)$ & $1.9 \pm 0.3(1.5-2.5)$ & $1.0 \pm 0.3(0.5-1.5)$ \\
FAL & $6.7 \pm 0.4(5.6-7.3)$ & $6.9 \pm 0.3(6.5-7.7)$ & $4.2 \pm 1.0(2.5-5.5)$ \\
HDL & $6.8 \pm 0.4(5.5-7.4)$ & $7.2 \pm 0.4(6.6-8.0)$ & $4.2 \pm 1.0(2.6-5.7)$ \\
TL & $15.2 \pm 0.8(13.7-16.9)$ & $16.0 \pm 0.7(14.4-17.0)$ & $9.2 \pm 2.3(5.2-17.0)$ \\
FL & $14.8 \pm 0.9(13.4-16.2)$ & $15.6 \pm 0.8(14.4-16.8)$ & $8.9 \pm 2.3(5.2-12.4)$ \\
VTL & $12.1 \pm 1.3(10-15)$ & $12.9 \pm 1.9(10-19)$ & $8.7 \pm 3.0(0-12)$ \\
VTR & $11.6 \pm 1.3(9-15)$ & $12.7 \pm 1.1(11-16)$ & $8.1 \pm 3.4(0-13)$ \\
\hline
\end{tabular}

Lower lip with a medial projection that fits into an indentation in upper lip. Choanae widely separated. Vomerine teeth present, located posterior to and between choanae; teeth in straight or slightly arched transverse rows, often irregularly arranged (occasionally there is a double row of teeth on one side); adult teeth 919 , with no apparent relation between number of teeth and regularity of arrangement. Juveniles have fewer teeth, 0-13 (one juvenile $11.7 \mathrm{~mm}$ SVL has no teeth at all, number of teeth increases with size among juveniles), and also exhibit irregular tooth arrangement in most individuals (including one double row in a juvenile $14.0 \mathrm{~mm}$ SVL). Maxillary teeth present.

Arms short and robust. Forearm as long as hand, usually with prominent row of tubercles on the distal side (present in $100 \%$ of the Kaieteur specimens, $40 \%$ of the Ayanganna specimens, $53 \%$ of the Wokomung specimens and $75 \%$ of the Merume specimens). Finger lengths in order of decreasing size III > I > II > IV; first finger slightly longer than second; finger tips rounded, not expanded; fingers without webbing or fringes. Two large prominent metacarpal tubercles; outer metacarpal tubercle circular, 1.5-2X size of ovoid inner metacarpal tubercle; subarticular tubercles well developed, ovoid, that on thumb largest, almost equal to inner metacarpal tubercle; palmar tubercles present; supernumerary tubercles present, rounded. Nuptial asperities absent (Figure 2).

Legs short and robust, shanks slightly longer than thighs. Toe lengths in order of decreasing size IV > III > V > II > I; toe tips expanded into small discs [state D of Heyer (1973)], discs not flattened; toes without webbing or fringes. Two prominent small metatarsal tubercles; inner metatarsal tubercle ovoid, 2-3X size of rounded 


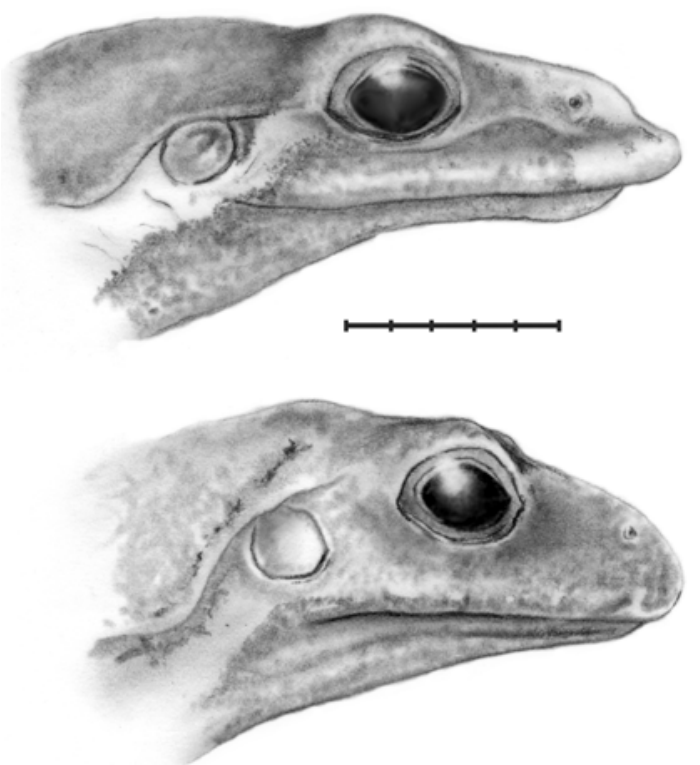

Figure 1 - Lateral profile of head of Leptodactylus lutzi. Top, male, ROM 43451; bottom, female, 43441. Scale bar $=5 \mathrm{~mm}$. Drawings AL.

outer metatarsal tubercle; subarticular tubercles well developed, ovoid; supernumerary tubercles present, rounded; sole of foot with several distinct tubercles; lower surface of tarsus with distinct white-tipped tubercles; tarsal fringe strongly developed in males, usually in contact with inner metatarsal tubercle, in females less well-developed, often not in contact with inner metatarsal tubercle; weak metatarsal fold formed by a row of tubercles present in some specimens (Figure 2).

Upper surfaces, including top of head and eyelids, with numerous small warty tubercles; a short postorbital glandular ridge, often prominent but may be represented only by a dark bar; dorsolateral and mid-dorsal glandular folds absent or barely visible; glandular belly fold present. Pustules and folds may be lost or less visible due to preservation. Two small black lumbar glands (Figure 3 B-D) are present in all but the smallest juveniles from Kaieteur,
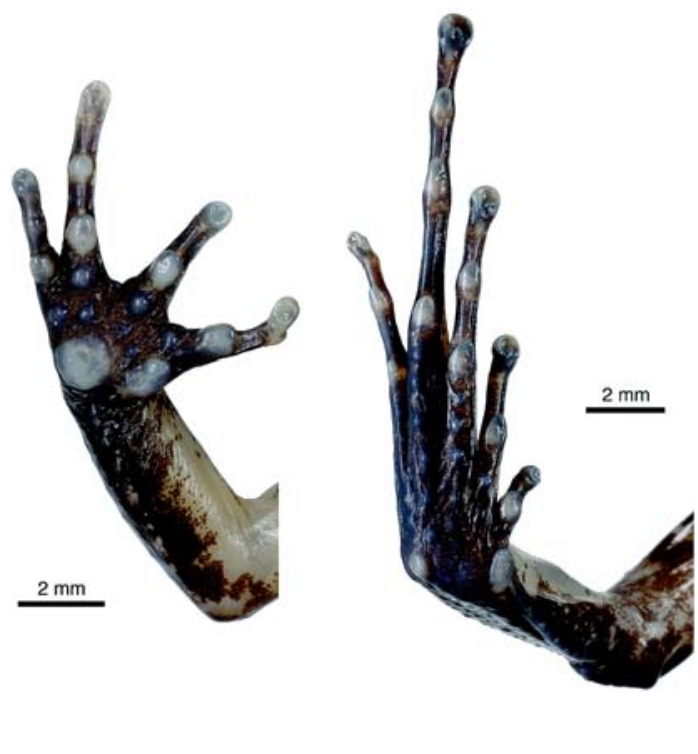

Figure 2 - Ventral views of (left) right hand and (right) right foot of a male Leptodactylus lutzi from Kaieteur National Park (IRSNB 13954). Photographs PJRK.

Ayanganna and Wokomung. In the six adult specimens from Merume Mountains the glands are visible in three individuals, although smaller than in specimens from other locations; in the other three individuals the glands are not visible.

Color in life - Leptodactylus lutzi exhibits a remarkable color-pattern polymorphism (Figures 4-5). We recognize five major color patterns among our sample: (Pattern A) dorsal ground color dark brown, grey or black with no or a barely discernible pattern; (Pattern B) dorsal ground color light to medium grey with well-defined pattern, characterized by a strongly marked dark brown to black interorbital bar and postorbital ridges, chevron between shoulders almost continuous with round lumbar spots and irregular dark brown to black markings on back; (Pattern C) similar to the preceding pattern, but with dorsal ground color light grey, brown or 


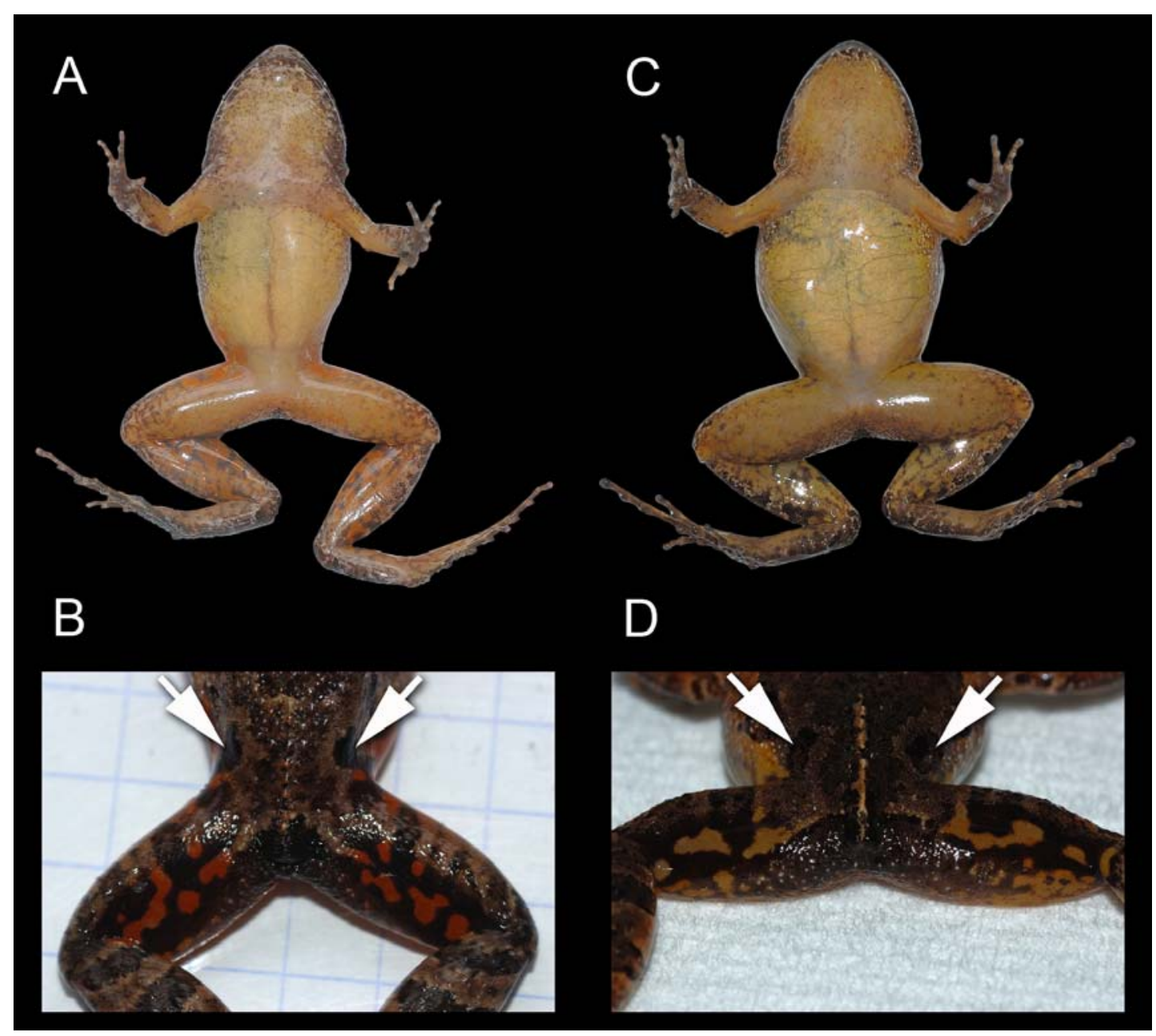

Figure 3 - (A) Ventral face of a male (IRSNB 13946) Leptodactylus lutzi in life; (B) Posterior surface of thighs of the same specimen; (C) Ventral face of a female (IRSNB 13945) L. lutzi in life; (D) Posterior surface of thighs of the same specimen. White arrows show black lumbar glands. Photographs PJRK.

reddish brown, with lighter, smaller, and much less evident markings on back (some of the markings may be absent); (Pattern D) rather similar to pattern B but with dark brown to black mottling on dorsum instead of welldefined markings; (Pattern E) dorsal ground color dark grey to black with large orange to orangish brown oblique lateral stripe; darker markings on back may be discernible or not.
There are many discrete variations within each major pattern: many specimens have a white stripe passing below tympanum from eye to arm insertion (95\% of specimens examined); in some this light stripe is expanded and encompasses the tympanum or a part of it $(62 \%$ of the Kaieteur specimens, $40 \%$ of the Ayanganna specimens, 32\% of the Wokomung specimens and $38 \%$ of the Merume specimens), 

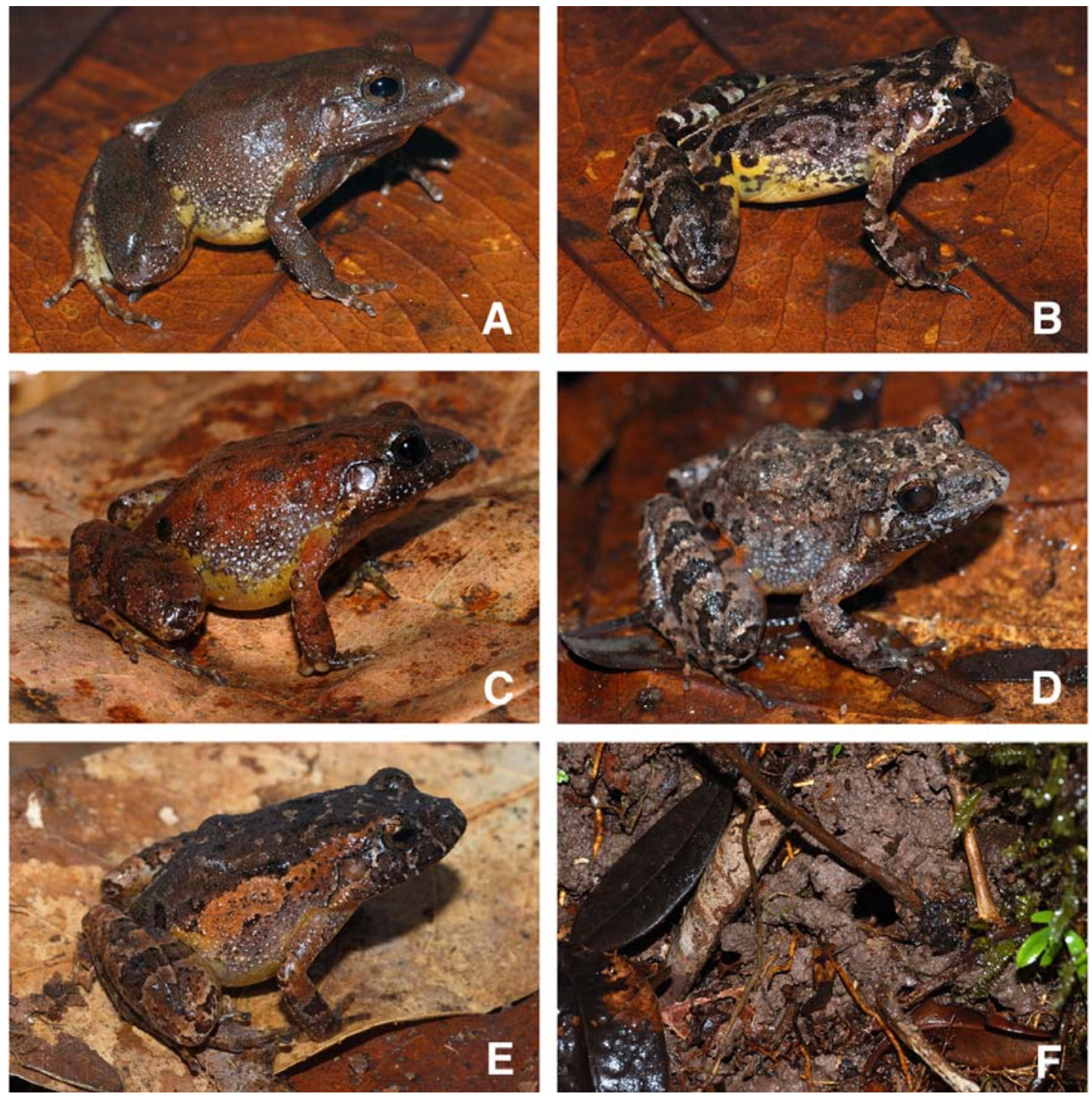

Figure 4 - Color-pattern polymorphism in living Leptodactylus lutzi and nesting chamber. (A) Pattern A, IRSNB 13956, male 30.4 mm SVL, Kaieteur National Park; (B) Pattern B, IRSNB 13953, female 34.0 mm SVL, Kaieteur National Park; (C) Pattern C, IRSNB 13950, male 29.8 mm SVL, Kaieteur National Park; (D) Pattern D, IRSNB 13946, male 29.9 mm SVL, Kaieteur National Park: (E) Pattern E, IRSNB 13945, female 32.4 mm SVL, Kaieteur National Park; (F) Nesting chamber. Photographs PJRK.

while in others the stripe is much narrower (35\% of the Kaieteur specimens, $40 \%$ of the Ayanganna specimens, 63\% of the Wokomung specimens and $63 \%$ of the Merume specimens), or absent (4\% of the Kaieteur specimens, $20 \%$ of the Ayanganna specimens, $5 \%$ of the Wokomung specimens). Several specimens from Mount Ayanganna (20\%) and Mount Wokomung 


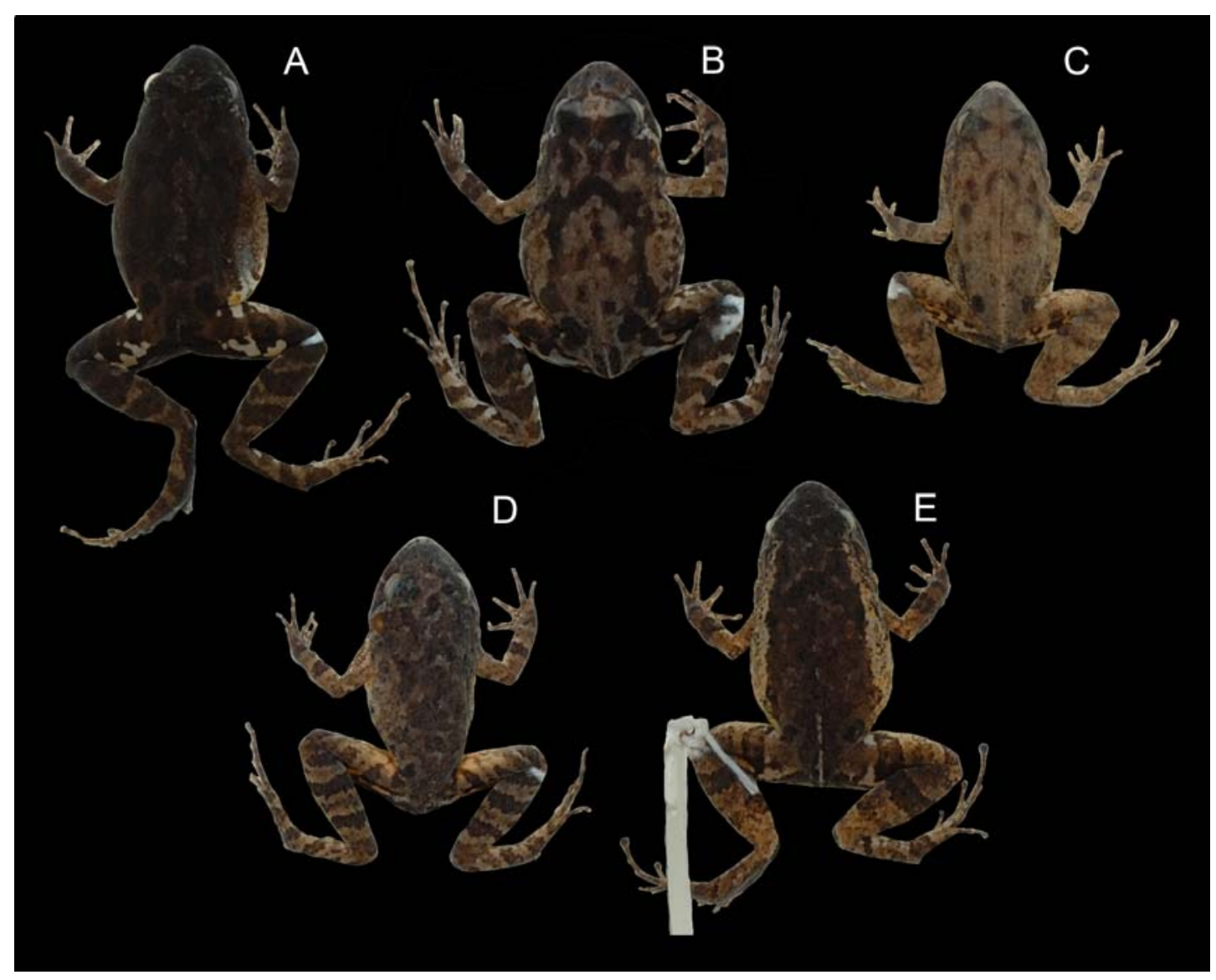

Figure 5 - Color-pattern polymorphism in preserved Leptodactylus lutzi. (A) Pattern A, IRSNB 13957, female 32.9 mm SVL, Kaieteur National Park; (B) Pattern B, IRSNB 13953, female 34.0 mm SVL, Kaieteur National Park; (C) Pattern C, IRSNB 13950, male 29.8 mm SVL, Kaieteur National Park; (D) Pattern D, IRSNB 13946, male 29.9 mm SVL, Kaieteur National Park; (E) Pattern E, IRSNB 13945, female 32.4 mm SVL, Kaieteur National Park. Photographs PJRK.

(42\%) have a diamond-shaped light patch between eyes, sometimes extending onto snout; this patch (never present in Pattern E specimens) is rare in specimens from KNP (less than 12\%) and absent in the Merume specimens. The black postorbital glandular ridge may sometimes touch the chevron, making the chevron resemble an " $\mathrm{X}$ " or a "W". A narrow yellow mid-dorsal stripe is present in many specimens (67\% of specimens examined, Figure 5C), often intermittent and, in some specimens, visible under magnification only. In most specimens of Pattern E, this stripe is broader and distinct in the sacral region (Figure 5E). Spots on posterior surface of thighs are variable in shape (rounded, oval, and sometimes anastomosed), color (pure yellow, yellowish orange or red on a black ground color) and number, but are always present (Figure 3 B-D). In life, ventral surfaces are always yellow to orangish yellow (Figure 3 
Table 2 - Frequencies (\%) of each major color pattern exhibited in Leptodactylus lutzi by locality. Three specimens from Merume Mountains were omitted from the table because of poor preservation.

\begin{tabular}{lccccc}
\hline Locality & A & B & C & D & E \\
\hline Kaieteur National Park (N = 26) & 27 & 4 & 38 & 4 & 27 \\
Mount Ayanganna (N = 5) & 20 & 0 & 60 & 0 & 20 \\
Mount Wokomung (N = 18) & 22 & 0 & 34 & 22 & 22 \\
Merume Mountains (N = 7) & 57 & 0 & 0 & 0 & 43 \\
\hline
\end{tabular}

A-C), usually suffused with dark grey stippling on throat, chest, and perimeter of belly; amount of ventral pigmentation is variable and not related to color pattern, but a darker dorsum is usually associated with more ventral melanophores. Centre of belly always lacking melanophores. Lower flank usually mottled and bearing many white-tipped tubercles; in most specimens there is a gradual change from dark dorsum to lighter venter, except in individuals with the pattern $\mathrm{E}$, in which the demarcation is sharp. Upper surfaces of arms and legs usually have darker crossbands (1-2 on arms, 2-4 on legs); crossbands are faint in some individuals, especially in specimens exhibiting pattern A. Dark brown or black seat patch is always present. Males, females and juveniles exhibit the same color-pattern polymorphism, but pattern $\mathrm{E}$ is rare in females; 13 of 15 (87\%) of pattern E are in males. Few individuals may be difficult to confidently assign to a particular color-pattern (especially when poorly preserved), but in most of the cases the five main patterns recognized here are easily distinguished. Frequencies of each major color-pattern exhibited by locality are summarized in Table 2. Regardless of locality, patterns $\mathrm{B}$ and $\mathrm{D}$ are the least commonly found among our sample (2\% and $9 \%$, respectively). Pattern $\mathrm{C}$ is the most frequent (34\%), patterns $\mathrm{A}$ and $\mathrm{E}$ are equally common (28 and 29\%, respectively). Patterns $\mathrm{A}$ and $\mathrm{E}$ are the only two patterns found in the Merume Mountains. Pattern B was observed only in Kaieteur National Park. The holotype of L. lutzi (Figure 1 in Heyer 1975) belongs to pattern $\mathrm{C}$.

Color in preservative - The five main patterns remain distinguishable in well preserved specimens. Some pattern E specimens from Merume Mountains retain a red pigment on the upper flanks and limbs which is different from the orange-red that is present in live animals. Some individuals that were grey in life became brownish in preservative, while others kept their grayish ground color. It is sometimes easier to distinguish the dorsal markings in preserved specimens than in living specimens, especially in individuals that exhibit pattern A.

Male secondary sexual characters - Males, including small specimens that were recognized as such, have a projecting shovel-shaped snout; we hypothesize that this fleshy proboscis is used to excavate underground nesting chambers; it is always absent in females. Males are slightly smaller than females, averaging $30.2 \mathrm{~mm}$ SVL ( $\mathrm{SD}=1.7, \mathrm{~N}=26$, $\max 33.5 \mathrm{~mm}$ ) vs. $31.2 \mathrm{~mm}$ SVL $(S D=1.7, N=19, \max 34.1 \mathrm{~mm})$ in females. Most males have a slightly distended subgular vocal sac with a greater number of melanophores located laterally on throat. Extent of tarsal fringe seems to be sexually dimorphic, with a more marked flap in males than in females.

Advertisement call - The call data refer to two of the three specimens recorded (IRSNB 13955 and IRSNB 13956); extraction of 

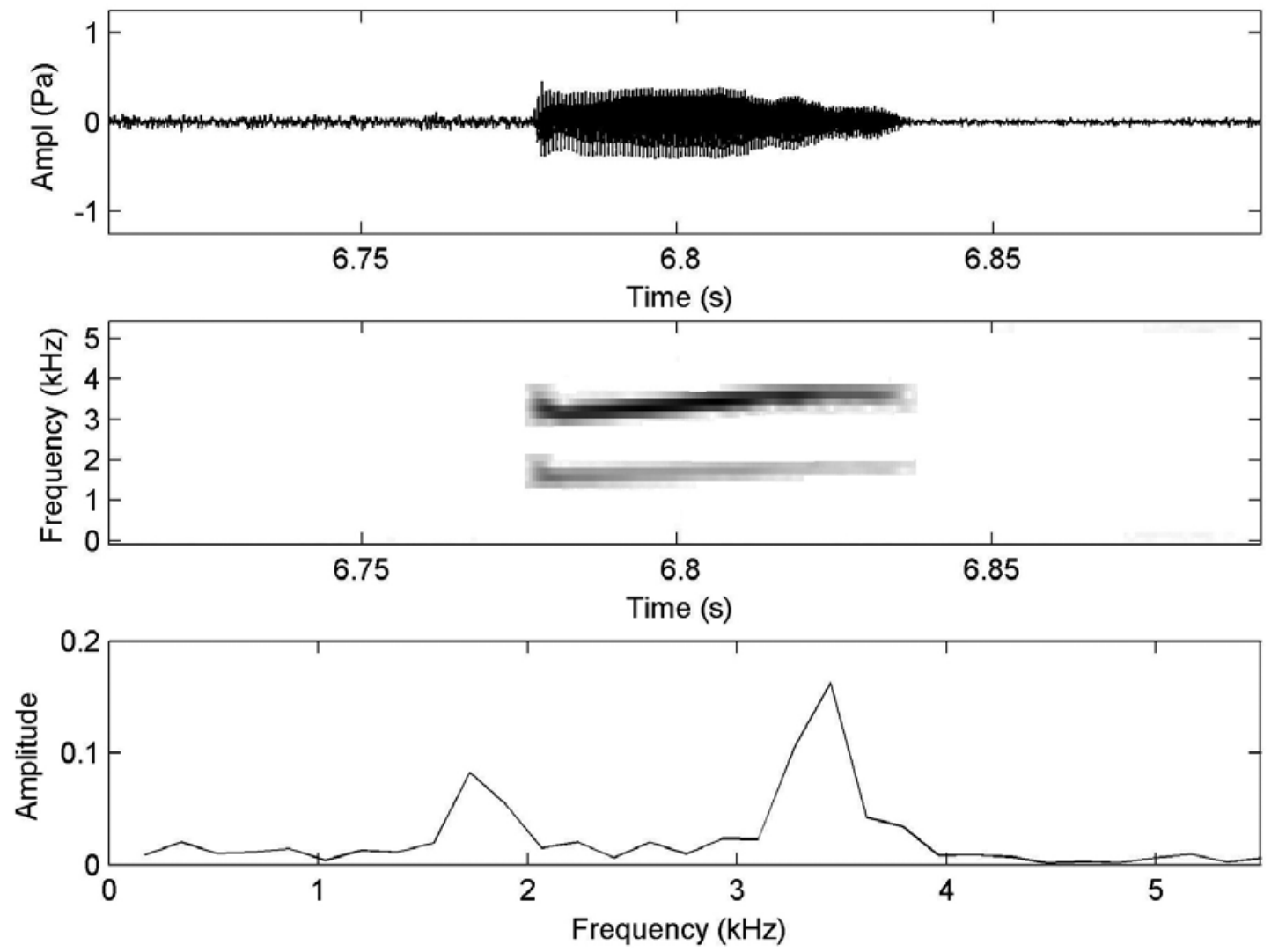

Figure 6 - Oscillogram (top), spectrogram (middle) and power spectrum (bottom) of the advertisement call of Leptodactylus lutzi (IRSNB 13955, recorded on 25 March 2006 at 22:40 h in Kaieteur National Park, Guyana; air temperature $\left.\mathrm{ca} .25^{\circ} \mathrm{C}\right)$.

measurements was not possible from the third specimen (unvouchered, long distance recording), and only call rate (calls/minute) was obtained from that individual. Only one call was analyzed for each vouchered male. The advertisement call of Leptodactylus lutzi (Figure 6 ) is a sequence of regular notes repeated about 17-23 times per minute. These notes last 41-64 ms (mean $54.27 \pm 9.96 \mathrm{~ms}$ ). The fundamental and dominant frequencies are $1722 \mathrm{~Hz}$ (1636$1808 \mathrm{~Hz})$ and $3445 \mathrm{~Hz}(3273-3617 \mathrm{~Hz})$, respectively. The call of $L$. lutzi is slightly frequency-modulated, with frequency modulation (FM) between $458-587 \mathrm{~Hz}$ (mean
$528.67 \pm 43.7 \mathrm{~Hz}$ ). Call rise time (CRT) is between 20.2-35 ms (mean $29.01 \pm 4.97 \mathrm{~ms}$ ). No pulse structure or upper harmonics were detected. Table 3 summarizes some acoustic parameters for Guianan and Amazonian species of the Leptodactylus marmoratus group.

\section{Revised diagnosis - Leptodactylus lutzi} differs from other members of the $L$. marmoratus species group by its advertisement call and the following combination of characters: (1) large size (males 25.7-33.5 mm SVL, females 27.1-34.1 mm SVL); (2) forearm tubercles present; (3) lower surface of tarsus 


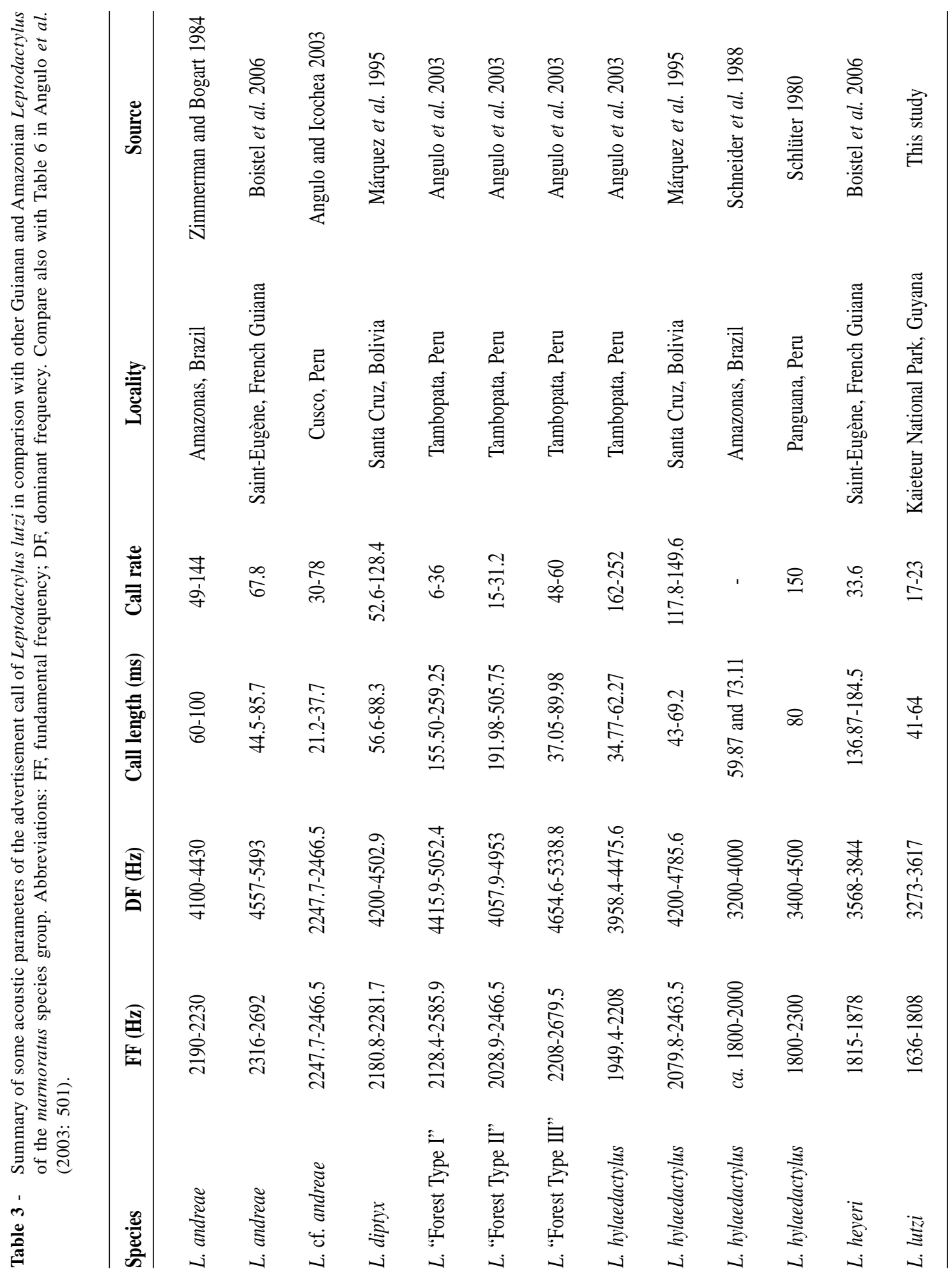


with distinct white-tipped tubercles; (4) males with yellow to orangish yellow throat and belly; (5) toe discs not flattened; (6) tarsal fringe strongly marked in males, often less visible in females; (7) mid-dorsal and dorsolateral folds absent or slightly visible; (8) white tubercles on tibia; (9) dark triangular seat patch present; (10) posterior surface of thigh black with distinct yellow, orange or red spotting or mottling.

Distribution and habitat - Up to this point, Leptodactylus lutzi was known only from three localities in Guyana: the holotype is from "Chinapoon River, upper Potaro", the two paratypes are from "Demerara Falls" (Heyer 1975), and Señaris and MacCulloch (2005) reported the species from Mount Ayanganna. As pointed out by Heyer (1975), the type locality is probably the Chenapou River (spelled “Chenapowu” River by Heyer) (045' N, $59^{\circ} 35^{\prime} \mathrm{W}$, elevation $448 \mathrm{~m}$ ), a stream south of the Amerindian village of Chenapou, about 54 $\mathrm{km}$ SW of Kaieteur Falls. The exact location of "Demerara Falls" is unknown to us, but we doubt that it is located on the Demerara River, which is located to the east of the highland habitat of L. lutzi. Actually "Demerara Falls" is probably located in the upper Mazaruni or upper Potaro area since $L$. lutzi has never been reported outside the Pakaraima Mountains in spite of extensive surveys in the Iwokrama Forest (Donnelly et al. 2004, 2005) and at Mabura Hill Forest Reserve (Ernst et al. 2005), two localities located closer to the Demerara River. Our specimens were collected from elevations ranging from 430-1400 $\mathrm{m}$ and substantially expand the distribution of the species to include most of the eastern part of the Pakaraima Mountains, west-central Guyana (Figure 7).

Leptodactylus lutzi is a terrestrial inhabitant of the submontane and lower montane primary forests of the Pakaraimas (ter Steege 2001). It is found in closed-canopy forests and was never observed in disturbed areas. Due to their peculiar reproductive habits (see below), adults do not appear to be dependent on bodies of water.

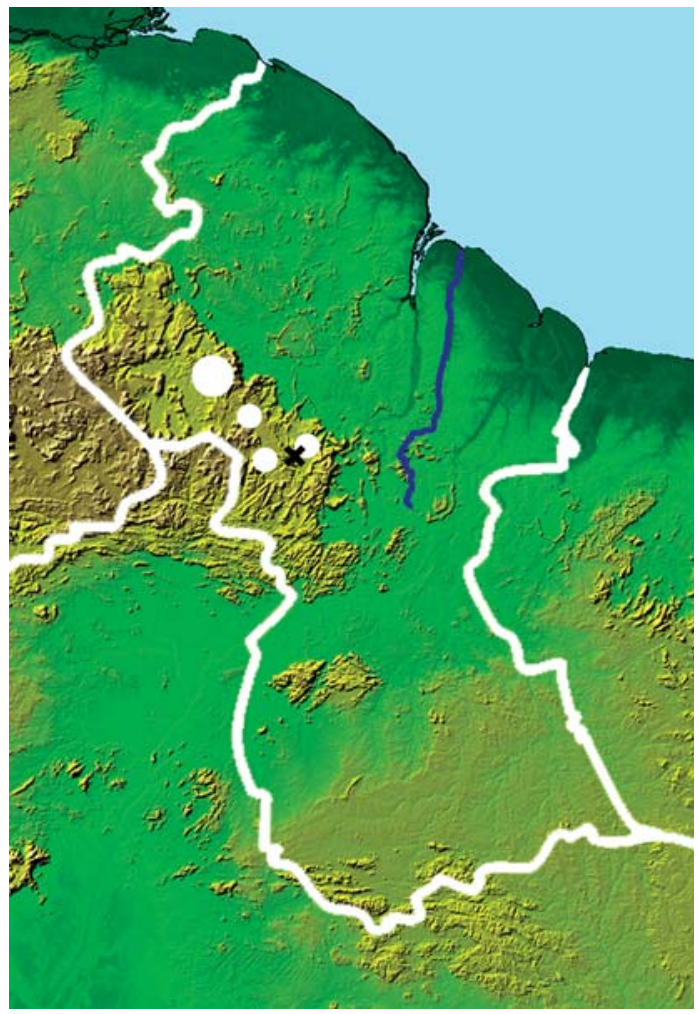

Figure 7 - Map of Guyana showing the distribution of Leptodactylus lutzi (white dots). Black $\mathrm{x}=$ type locality, the blue line indicates the Demerara River. Map courtesy NASA/JPL.

Leptodactylus lutzi may be locally common; specimens were found in or on the leaf litter.

Reproductive biology - Leptodactylus lutzi is mainly nocturnal. Males call from the surface of or under the leaf litter, usually at night during heavy rains; in KNP several males were calling on a late afternoon after a short rainfall in March 2006.

Reproduction appears to be constrained to the wettest months of the year. No males were calling during dry periods; this is to be expected since excavation of nesting chambers requires wet soils. Many calling males were observed in March 2006, which was exceptionally rainy. 
Courtship was observed by PJRK and Paul Benjamin in the southeastern part of the park on 19 March 2006 at 21:10 h. Rain was falling heavily that night and many males were calling not far from a small trail within the primary forest. No territorial interaction was observed and the call emitted during courtship sounded identical to the advertisement call (not recorded). A female was detected on the ground, attracted by a male that was calling energetically. The male was probably trying to lead the female into an already excavated nesting chamber located between roots at the base of a tree, far from any body of water (Figure 4F). Chamber construction was not observed. The male was calling adjacent to the chamber's entrance and when the female approached very close, without touching him, he entered the chamber, head first. Once in the chamber he resumed calling. The female appeared to miss the entrance and disappeared into the leaf litter. A few seconds later the male put its head outside the hole, calling constantly. The female reappeared, but missed the entrance several times. Each time the male emerged from the chamber and called at the entrance until the female reappeared, at which point he re-entered the chamber, calling continuously. After several minutes, the female found the entrance and followed the male into the nesting chamber; at this time we decided to leave the pair and return the next day. The next morning we took several photographs of the exterior of the chamber, then opened it. The chamber consisted of a spherical hole with no entrance tunnel (no measurements taken). The nesting chamber was empty and we speculated that the mating process finally failed. Seven females collected in KNP in January, March, July and December have 3-10 enlarged white ova of 0.9-4.4 mm diameter. No enlarged ova were observed in specimens from Ayanganna or Merume, collected in October and August respectively; of the eight adult females collected from Wokomung in October and November, only one contained slightly enlarged ova (1 mm diameter).

\section{Discussion}

The specimens of $L$. lutzi examined in this study conform to the original description (Heyer 1975). Any differences between the description in Heyer (1975) and this paper are because the latter is based on a larger number of specimens, from a wider distribution.

The advertisement call of Leptodactylus lutzi can be distinguished from the calls of all the Guianan and Amazonian members of the $L$. marmoratus species group by the combination of lower fundamental (1636-1808 Hz) and dominant frequencies (3273-3617 Hz) (which is consistent with an increase in the body size) and lower call rate (17-23 notes/min). Like in all other members of the $L$. marmoratus species group, with exception of $L$. cf. andreae (Angulo and Icochea 2003), and L. marmoratus from Boracéia, São Paulo, Brazil (Heyer et al. 1990, see also Kwet and Angulo 2002), the dominant frequency of the call of $L$. lutzi is the second harmonic.

Morphological evidence suggests that males of Leptodactylus lutzi may excavate underground nesting chambers using their shovel-shaped snout, as reported in males of the L. fuscus group (Martins 1988, Freitas et al. 2001, Reading and Jofré 2003, Giaretta and Kokubum 2004) and an undescribed species of the L. marmoratus group (Kokubum and Giaretta 2005). Like males of the L. fuscus group (Martins 1988, Giaretta and Kokubum 2004), L. lutzi males lead females to a previously excavated underground nesting chamber. As far as we know, this behavior is shared by at least three species of the $L$. marmoratus group: L. diptyx (De la Riva 1995, 1996), an undescribed species from Minas Gerais, southeastern Brazil (Kokubum and Giaretta 2005) and an undescribed species from Acre, western Brazil (Kokubum and Souza, unpublished data). The tadpole of $L$. lutzi remains unknown, but as nesting chambers are built far away from any body of water we hypothesize that it may be endotrophic and that complete development may occur within the 
chamber [mode 22 of Duellman and Trueb (1986)], like in other species of the $L$. marmoratus group (Heyer and Silverstone 1969, Lutz 1947). Few eggs and large diameter of ova also support the terrestrial mode hypothesis.

Few herpetological surveys have been conducted in Guyana and the country's herpetofauna remains poorly known. As stated above, besides Leptodactylus lutzi, only two species of the L. marmoratus group are reported from Guyana: $L$. andreae and $L$. hylaedactylus. We found only a few published records of these species in Guyana. Leptodactylus andreae is reported from the extreme south of the country, north of Acarai Mountains and Shudikar-wau (Heyer 1973), from Iwokrama Forest (Donnelly et al. 2004, 2005) and Mabura Hill Forest Reserve (Ernst et al. 2005). In Guyana, the species has not been reported from the Pakaraima region and could be absent from the area. Leptodactylus hylaedactylus seems more widespread, being reported from several localities throughout Guyana, from Yarikita River in the northwest to Marudi in the south (Heyer 1973). The species is absent from Iwokrama Forest (Donnelly et al. 2004, 2005) and Mabura Hill Forest Reserve (Ernst et al. 2005), but it has been reported from Membaru River in the Pakaraima region (Heyer 1973). It must be noted that RDM and AL collected several specimens of a possibly undescribed member of the L. marmoratus species group on Mount Wokomung.

\section{Acknowledgements}

We thank Paul Benjamin, Giuliano "Kinky" Seegobin, Samir Khan, Brad Hubley and Carter Cox for field assistance, and the Rahaman family (Menzies Landing) for providing logistic support. Les Minter (UL) provided distribution data and kindly allowed us to examine specimens he collected in the Merume Mountains. Sébastien Bruaux and Christophe De Mey (IRSNB) provided technical help in Brussels. We warmly acknowledge the enthusiastic and helpful support of the Prime Minister of Guyana, the Honorable Samuel Hinds, and that of Ambassador Patrick Gomes and Myrna Vincke from the Embassy of Guyana, Brussels. Fieldwork of PJRK was funded by the DGDC (Directorate-General for Development Cooperation) through the Belgian Focal Point to the Global Taxonomy Initiative. Fieldwork of RDM and AL was made possible with the generous support of the ROM Reproductions Acquisitions Fund and the ROM Centre for Biodiversity and Conservation Biology. Research and export permits for the specimens (research permits 121004BR019, 180604BR011, 120704BR014, 030605BR006; export permits 100804SP010, 191104SP016, 031204SP017, 191205SP011, 040406SP014, 040706SP017) were obtained thanks to Indarjit Ramdass, Ramesh Lilwah, Annie Pitamber and Clydecia McClure of the Environmental Protection Agency (EPA), Guyana, and Michelle Kalamandeen and Calvin Bernard of the University of Guyana. Finally we thank Ariadne Angulo and an anonymous reviewer for their critical reading of the manuscript and helpful comments. This is contribution 333 of the Centre for Biodiversity and Conservation Biology, ROM and number 118 in the Smithsonian's Biological Diversity of the Guiana Shield Program publication series.

\section{References}

Almeida, A. P. and A. Angulo. 2006. A new species of Leptodactylus (Anura: Leptodactylidae) from the state of Espírito Santo, Brazil, with remarks on the systematics of associated populations. Zootaxa 1334: 1-25.

Angulo, A. and J. Icochea. 2003. Adenomera cf. andreae (NCN). Vocalization. Herpetological Review 34: 48-49.

Angulo, A., R. B. Cocroft and S. Reichle. 2003. Species identity in the genus Adenomera (Anura: Leptodactylidae) in southeastern Peru. Herpetologica 59: 490-504.

Boistel, R., J.-C. de Massary and A. Angulo. 2006. Description of a new species of the genus Adenomera (Amphibia, Anura, Leptodactylidae) from French Guiana. Acta Herpetologica 1: 1-14.

Cocroft, R. B. and M. J. Ryan. 1995. Patterns of advertisement call evolution in toads and chorus frogs. Animal Behaviour 49: 282-303. 
De la Riva, I. 1995. A new reproductive mode for the genus Adenomera (Amphibia: Anura: Leptodactylidae): taxonomic implications for certain Bolivian and Paraguayan localities. Studies on Neotropical Fauna and Environment 30: 15-29.

De la Riva, I. 1996. The specific name of Adenomera (Anura: Leptodactylidae) in the Paraguay Basin. Journal of Herpetology 30: 556-558.

Donnelly, M. A., M. H. Chen and G. G. Watkins. 2004. Sampling amphibians and reptiles in the Iwokrama Forest ecosystem. Proceedings of the Academy of Natural Sciences of Philadelphia 154: 55-69.

Donnelly, M. A., M. H. Chen and G. G. Watkins. 2005. The Iwokrama Herpetofauna: An Exploration of Diversity in a Guyanan Rainforest. Pp. 428-460 in M. A. Donnelly, B. I. Crother, C. Guyer, M. H. Wake and M. E. White (eds.), Ecology and Evolution in the Tropics: A Herpetological Perspective. University of Chicago Press.

Duellman, W. E. and R. A. Pyles. 1983. Acoustic resource partitioning in anuran communities. Copeia 1983: 639-649.

Duellman, W. E. and L. Trueb. 1986. Biology of Amphibians. McGraw-Hill Book Co., New York. 670 pp.

Ernst, R., M.-O. Rödel and D. Arjoon. 2005. On the cutting edge - The anuran fauna of the Mabura Hill Forest Reserve, Central Guyana. Salamandra 41: 179-194.

Freitas, E. F. L., E. F. Spirandeli-Cruz and J. Jim. 2001. Comportamento reprodutivo de Leptodactylus fuscus (Schneider, 1799) (Anura: Leptodactylidae). Comunicações do Museu de Ciência e Tecnologia, PUCRS, Série Zoologia 14: 121-132.

Frost, D. R., T. Grant, J. Faivovich, R. H. Bain, A. Haas, C. F. B. Haddad, R. O. de Sá, A. Channing, M. Wilkinson, S. C. Donnellan, C. J. Raxworthy, J. A. Campbell, B. L. Blotto, P. Moler, R. C. Drewes, R. A. Nussbaum, J. D. Lynch, D. M. Green and W. C. Wheeler. 2006. The Amphibian Tree of Life. Bulletin of the American Museum of Natural History 297: 1-370.

Giaretta, A. A. and M. N. C. Kokubum. 2004. Reproductive ecology of Leptodactylus furnarius Sazima \& Bokermann, 1978, a frog that lays eggs in underground chambers (Anura, Leptodactylidae). Herpetozoa 16: 115-126.

Gridi Papp, M. 2004. Sound Ruler, V0941. http:// soundruler.sourceforge.net.

Hayek, L. A., W. R. Heyer and C. Gascon. 2001. Frog morphometrics: a cautionary tale. Alytes 18: 153-177.

Heyer, W. R. 1973. Systematics of the marmoratus group of the frog genus Leptodactylus (Amphibia, Leptodactylidae). Contributions in Science, Natural History Museum, Los Angeles County 251: 1-50.
Heyer, W. R. 1975. Adenomera lutzi (Amphibia: Leptodactylidae), a new species of frog from Guyana. Proceedings of the Biological Society of Washington 88: 315-318.

Heyer, W. R. and P. A. Silverstone. 1969. The larva of the frog Leptodactylus hylaedactylus (Leptodactylidae). Fieldiana, Zoology 51: 141-145.

Heyer, W. R., A. S. Rand, C. A. G. Cruz, O. L. Peixoto and C. E. Nelson. 1990. Frogs of Boracéia. Arquivos de Zoologia, São Paulo 31: 231-410.

Kokubum, M. N. C. and A. A. Giaretta. 2005. Reproductive ecology and behavior of a species of Adenomera (Anura, Leptodactylinae) with endotrophic tadpoles: systematics implications. Journal of Natural History 39: 1745-1758.

Kwet, A. and A. Angulo. 2002. A new species of Adenomera (Anura, Leptodactylidae) from the Araucaria forest of Rio Grande do Sul (Brazil), with comments on the systematic status of southern populations of the genus. Alytes 20: 28-43.

Lutz, B. 1947. Trends towards non-aquatic and direct development in frogs. Copeia 1947: 242-252.

Márquez, R., I. De la Riva and J. Bosch. 1995. Advertisement calls of Bolivian Leptodactylidae (Amphibia, Anura). Journal of Zoology 237: 313336.

Martins, M. 1988. Biologia reprodutiva de Leptodactylus fuscus em Boa Vista, Roraima (Amphibia, Anura). Revista Brasileira de Biologia 48: 969-977.

Reading, C. J. and G. M. Jofré. 2003. Reproduction in the nest building vizcacheras frog Leptodactylus bufonius in central Argentina. Amphibia-Reptilia 24: 415-427.

Schlüter, A. 1980. Bio-akustische untersuchungen an leptodactyliden in einem begrenzten gebiet des tropischen regenwaldes von Peru. Salamandra 16: 227-247.

Schneider, H., G. Joermann and W. Hödl. 1988. Calling and antiphonal calling in four neotropical anuran species of the family Leptodactylidae. Zoologische Jahrbücher Abteilung für Allgemeine Zoologie und Physiologie der Tiere 92: 77-103.

Señaris, J. C. and R. D. MacCulloch. 2005. Amphibians. Pp. 9-23 in T. Hollowell and R. P. Reynolds (eds.), Checklist of the Terrestrial Vertebrates of the Guiana Shield. Bulletin of the Biological Society of Washington 13.

ter Steege, H. 2001. National Vegetation Map of Guyana. Guyana Forestry Commission: Georgetown.

Zimmerman, B. L. and J. P. Bogart. 1984. Vocalizations of primary forest frog species in the Central Amazon. Acta Amazonica 14: 473-519. 
Appendix I - Specimens Examined

Leptodactylus andreae - FRENCH GUIANA: Régina: Pic Matécho $\left(03^{\circ} 45^{\prime} \mathrm{N}\right.$, 5302'W, ca. $400 \mathrm{~m}$ ), IRSNB 13004, IRSNB 13016, IRSNB 13023. Roura: Crique Bagot, Dégrad Kwata (0432' N, 52³3’ W, ca. 30 m), IRSNB 12766, IRSNB 13964-66. Saül: Saül, Montagne Belvédère $\left(03^{\circ} 37^{\prime} \mathrm{N}, 53^{\circ} 10^{\prime} \mathrm{W}, \mathrm{ca}\right.$. $250 \mathrm{~m})$, IRSNB 12752, IRSNB 12891, IRSNB 12897, IRSNB 12981-87, IRSNB 12903, IRSNB 12937.

Leptodactylus heyeri - FRENCH GUIANA: Roura: Crique Bagot, Dégrad Kwata (0432’ N, 52³3' W, ca. 30 m), IRSNB 13963. Saül: Saül, Montagne Belvédère $\left(03^{\circ} 37^{\prime} \mathrm{N}, 53^{\circ} 10^{\prime} \mathrm{W}, c a\right.$. 250 m), IRSNB 12985.

Leptodactylus hylaedactylus - GUYANA: Barima-Waini: Baramita $\left(07^{\circ} 22^{\prime} \mathrm{N}, 60^{\circ} 29^{\prime} \mathrm{W}\right.$, ca. $100 \mathrm{~m})$, ROM 22760.

Leptodactylus lutzi - GUYANA: CuyuniMazaruni: Mount Ayanganna: base $\left(05^{\circ} 25^{\prime} \mathrm{N}\right.$, 5958' W, 850 m), ROM 40155. Northeast plateau $\left(05^{\circ} 24^{\prime} \mathrm{N}, 59^{\circ} 57^{\prime} \mathrm{W}, 1500 \mathrm{~m}\right)$, ROM 39998-9, ROM 40165, ROM 40167, USNM 546152. Merume Mountains: 06 ${ }^{\circ} 10^{\prime}$ N, 60²6’
W, 700m, ROM 44126-7. 0602' N, 60 $16^{\prime} \mathrm{W}$,

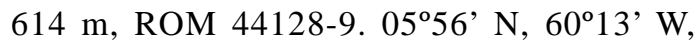
930m, ROM 44130-2. Partang vicinity (06 $03^{\circ}$ N, 6007' W, elevation unknown), ROM 441235. Potaro-Siparuni: Kaieteur National Park: Tukeit trail $\left(05^{\circ} 11^{\prime} \mathrm{N}, 5^{\circ} 28^{\prime} \mathrm{W}\right.$, elevation $c a$. $480 \mathrm{~m}$ ), IRSNB 13937, IRSNB 13939-42, IRSNB 13944-50, IRSNB 13959. Muri Muri trail (0510' N, 59²9' W, elevation ca. $430 \mathrm{~m}$ ), IRSNB 13938. Arthur Simon's trail, right bank Potaro River (0509' N, 59 $29^{\prime}$ ' W, elevation $c a$. $440 \mathrm{~m})$, IRSNB 13943. Sir Donald's trail, near base camp \#2 (05 $08^{\prime} \mathrm{N}, 5^{\circ} 25^{\prime} \mathrm{W}$, elevation $c a$. 540 m), IRSNB 13951, IRSNB 13955-58. Base camp \#2 Elinkwa (0508' N, 59²5' W, elevation ca. $530 \mathrm{~m}$ ), IRSNB 13952-53, IRSNB 1396061. Amu trail $\left(05^{\circ} 08^{\prime} \mathrm{N}, 5^{\circ} 24^{\prime} \mathrm{W}\right.$, elevation $c a$. $580 \mathrm{~m})$, IRSNB 13954, IRSNB 13962. Mount Wokomung: northeast, between base of mountain and Potaro River $\left(05^{\circ} 08^{\prime} \mathrm{N}\right.$, 594' W, $700 \mathrm{~m}$ ), ROM 43437-43. North slope $\left(05^{\circ} 07^{\prime} \mathrm{N}, 59^{\circ} 49^{\prime} \mathrm{W}, 1230 \mathrm{~m}\right)$, ROM 43444-52. North slope $\left(05^{\circ} 06^{\prime} \mathrm{N}, 59^{\circ} 51^{\prime} \mathrm{W}\right.$, 1400 m), ROM 43453-55. 